\title{
Perceptions of ecosystem services provided by tropical forests to local populations in Cameroon
}

\author{
Simon Lhoest ${ }^{\mathrm{a}, *}$, Marc Dufrêne ${ }^{\mathrm{a}}$, Cédric Vermeulen ${ }^{\mathrm{a}}$, Johan Oszwald ${ }^{\mathrm{b}}$, Jean-Louis Doucet ${ }^{\mathrm{a}}$, \\ Adeline Fayolle ${ }^{\mathrm{a}}$ \\ ${ }^{a}$ University of Liège, Gembloux Agro-Bio Tech, Passage des Déportés 2, 5030 Gembloux, Belgium \\ ${ }^{\mathrm{b}}$ University of Rennes, UFR Social Sciences, Department of Geography/Planning, Place du Recteur Henri Le Moal CS 24307, 35043 Rennes cedex, France
}

\section{A R T I C L E I N F O}

\section{Keywords:}

Ecosystem services

Perception

Social assessment approach

Protected area

Logging concession

Community forest

\begin{abstract}
A B S T R A C T
In Central Africa, local populations are deeply dependent on tropical forests, which provide numerous ecosystem services (ES). For the first time in Central Africa, we assessed the perceptions of ES provided by tropical forests to local populations, considering three land allocation types: a protected area, a Forest Stewardship Council (FSC)certified logging concession, and three community forests. We conducted a questionnaire survey with 225 forest stakeholders in southeastern Cameroon, combining an open-ended question and 16 directed questions to evaluate the perceptions of ES significance and abundance, respectively. The ES most frequently reported as significant were provisioning (93\% of respondents) and cultural \& amenity services (68\%), whereas regulating services were less mentioned (16\%). Bushmeat provision was the only ES perceived as highly significant but not very abundant. There were slight variations of perceptions among forest land allocation types and respondents, suggesting a relative homogeneity in ES abundance. For further integrative ES assessment, we suggest quantifying ES with complementary ecological and economic approaches, such as meat provision, recreation, tourism, timber provision, spiritual experience, firewood provision, water quality regulation, and inspiration for culture. We also give three concrete recommendations for forest management, the most urgent being to provide sources of protein alternative to bushmeat.
\end{abstract}

\section{Introduction}

Ecosystem services (ES) are the contributions of ecosystems to human well-being (Burkhard et al., 2012). They classically include provisioning, regulating, and cultural services (de Groot et al., 2010a). ES constitute a conceptual tool that integrates human-nature relationships (Turner and Daily, 2008) and contributes to the implementation of concrete policies and practices for the sustainable use of all ecosystems.

In order to guide decision makers towards ecological sustainability, economic efficiency, and social justice, any complete ES assessment should use an integrated approach that combines relevant methods (Costanza, 2000; Farley, 2012; Millennium Ecosystem Assessment, 2005). Integrated valuations combine ecological, economic, and social approaches (Burkhard et al., 2010; Felipe-Lucia et al., 2015; Jacobs et al., 2016). Ecological approaches measure the ecological functions or ecosystem biophysical properties (Boeraeve et al., 2015; de Groot et al., 2002); economic approaches give values to ES in monetary terms
(Wilson and Carpenter, 1999); and social approaches focus on the values that society attributes to each ES (Martín-López et al., 2012). Current ES assessments mainly focus on the ecological and/or economic approaches (Satz et al., 2013), whereas social approaches are rarely implemented (Kremen and Ostfeld, 2005; Boeraeve et al., 2015). However, social approaches are fundamental to better understand complex social-ecological systems (Orenstein and Groner, 2014). To ensure optimal provision of ES on which humans rely (Rosenberg and McLeod, 2005), it is essential to integrate all stakeholders' perceptions in sustainable management strategies and decisions (Braat and de Groot, 2012; Castro et al., 2011; Collins et al., 2010). The decision making process should incorporate the societies' perceptions in order to: (i) legitimize strategies and decisions, meeting multiple stakeholders' interests (Martín-López et al., 2012; Menzel and Teng, 2009); (ii) anticipate likely reactions, behavior, and compliance of key stakeholders to new regulations and measures (Gelcich et al., 2009; Gelcich and O'Keeffe, 2016; Hicks and Cinner, 2014); and (iii) identify agreement areas (Hicks et al., 2013).

\footnotetext{
* Corresponding author.

E-mail addresses: simon.lhoest@uliege.be (S. Lhoest), marc.dufrene@uliege.be (M. Dufrêne), cvermeulen@uliege.be (C. Vermeulen), johan.oszwald@univ-rennes2.fr (J. Oszwald), jldoucet@uliege.be (J.-L. Doucet), adeline.fayolle@uliege.be (A. Fayolle).
} 


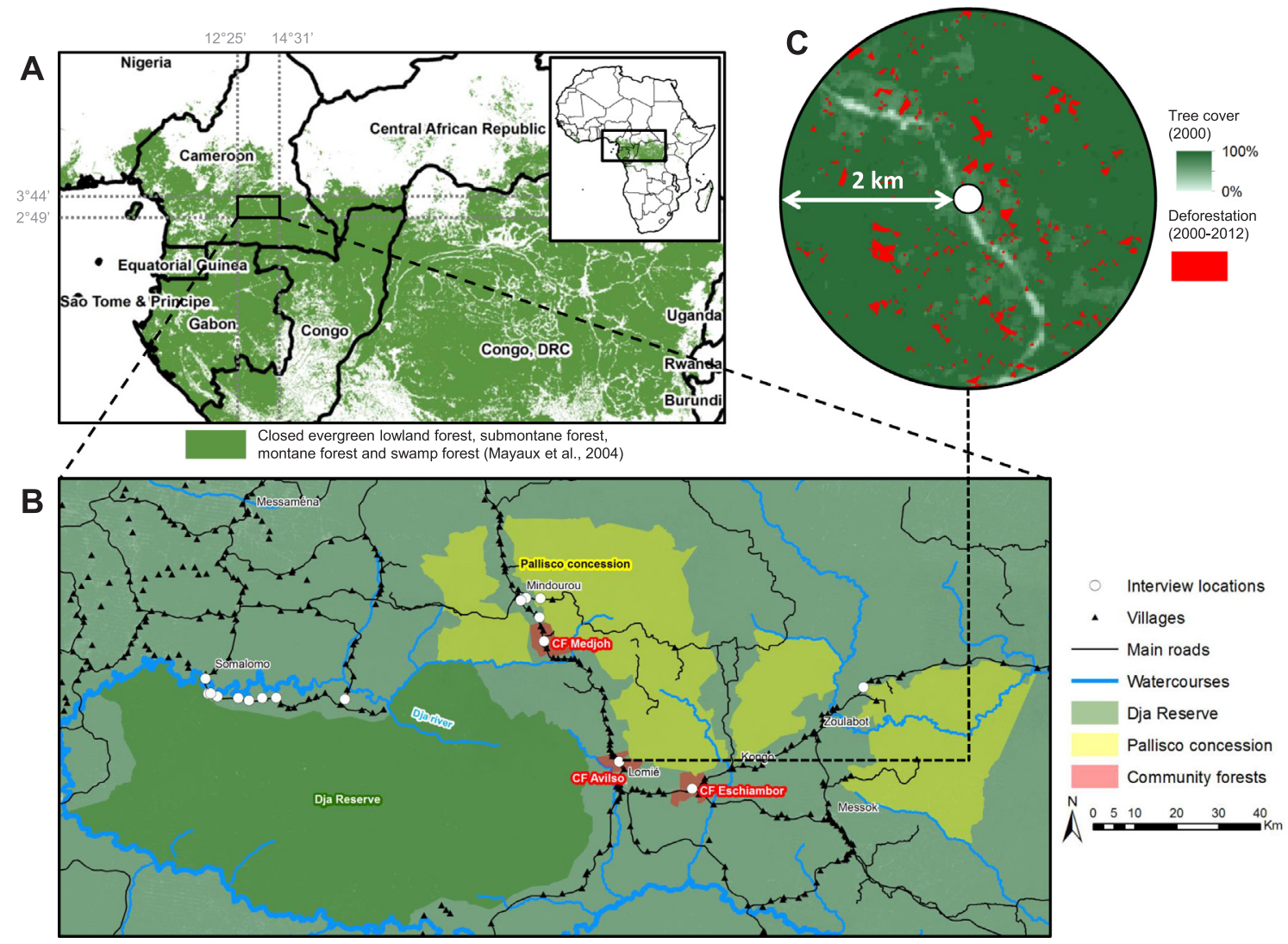

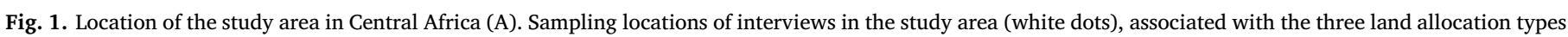

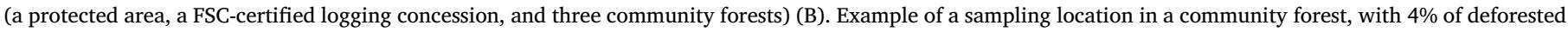
areas between 2000 and 2012 (red polygons; Hansen et al., 2013) in a radius of $2 \mathrm{~km}$ (C).

Each ES assessment should be initiated with a social approach to consider the perceptions of local stakeholders (Cuni-Sanchez et al., 2016); furthermore, social methodologies to assess ES are currently disparate (Felipe-Lucia et al., 2015; Menzel and Teng, 2009) and standard approaches need to be developed. Santos-Martín et al. (2017) reviewed seven methods that are frequently used in ES literature, dealing with different data types adapted to several valuation purposes: preference assessment (e.g., Martín-López et al., 2012), time use method (e.g., García-Llorente et al., 2016), photo-elicitation surveys (e.g., García-Llorente et al., 2012), narrative methods (e.g., Kovács et al., 2015), participatory mapping (e.g., Plieninger et al., 2013), scenario planning (e.g., Bohensky et al., 2006), and deliberative methods (e.g., Karjalainen et al., 2013). Despite an ongoing debate on ES and nature's contributions to people (NCP) concepts, raised by Díaz et al. (2018), we adopted the ES framework while integrating social approaches in assessments, and emphasize the importance of doing so.

Central Africa is home to approximately 113 million people, with more than 23 million living in Cameroon (Abernethy et al., 2016). Central African forests provide a diversity of provisioning, regulating, and cultural ES, offering wood and means of subsistence to 60 million people living either inside or in the vicinity of forests (de Wasseige et al., 2015), particularly through hunting and gathering non-timber forest products (NTFP). These forests also constitute large carbon stocks that influence global climate (Pan et al., 2011), and host an important part of the world's terrestrial biodiversity (Mallon et al., 2015). Human populations also attribute a variety of socio-cultural values to Central African forests (Vermeulen, 2000). Although deforestation rates are still relatively low in Central Africa in comparison to other tropical regions (Achard et al., 2014), these forests will face multiple human pressures in the near future (Malhi et al., 2014). Environmental changes could soon be observed due to increasing human populations, demand for economic growth, global climate change, overexploitation, and weak governance (Abernethy et al., 2016).

Local-scale assessments of multiple ES provided by Central African tropical forests are urgent and crucial, but none have been made yet (Wangai et al., 2016). These complex social-ecological systems are influenced by several groups of stakeholders with contrasting interests and uses of resources (Gillet et al., 2016; Janssen et al., 2007), and constitute a high-priority stake considering their contribution to human life quality in a high-poverty context. For the maintenance of future ES flows and sustainability objectives for forest land management, assessment of both ES significance and abundance is required. It is also essential to comprehend how the stakeholders' perceptions of ES are shaped by their surrounding environment (Hartter et al., 2014; QuintasSoriano et al., 2016) such as forest land allocation and deforestation, and by socio-demographic characteristics (Carpenter et al., 2006; Zhang et al., 2016) to properly align forest land planning strategies (protection, production, or community management) with stakeholders' needs and uses in a sustainable manner.

The main objective of this study was to assess the perceptions of ES provided by tropical forests to local populations in southeastern Cameroon. We specifically aimed to: (i) assess the significance and abundance of ES; and (ii) identify any differences in the perceptions of ES abundance among three forest land allocation types (a protected area, a logging concession, and community forests), among areas with different deforestation rates in previous years, and among respondents with distinct socio-demographic characteristics (gender, age, ethnicity, and main occupation). Hereafter, we define the "perceptions" of ecosystem services as the cognition of usefulness and interests of the forest for its contributions to the well-being of local human populations (Attneave, 1962). We consider "land allocation types" as resulting from a planning and zoning process identifying explicit geographical areas 
with allowed practices (Oyono et al., 2014).

We hypothesize that ES abundance varies among contrasting forest land allocation types, considering the differences in access to forest resources and user rights for local populations. Using a social approach with novel data in a data-deficient region, our study provides insights on the importance and perceived supply of ES, and the ability of contrasting forest land allocation types to provide abundant ES to local populations. It also contributes significantly in the understanding of the socio-demographic characteristics shaping the ES perceptions of forest stakeholders in rural areas of a developing country in Central Africa.

\section{Material and methods}

\subsection{Study area}

The study area was located in southeastern Cameroon, between latitude $2^{\circ} 49^{\prime} \mathrm{N}$ to $3^{\circ} 44^{\prime} \mathrm{N}$ and longitude $12^{\circ} 25^{\prime} \mathrm{E}$ to $14^{\circ} 31^{\prime} \mathrm{E}$ (Fig. 1 ). The annual rainfall is around $1640 \mathrm{~mm}$ with two distinct rainy seasons (August to November, and March to June), the mean annual temperature is $23.1^{\circ} \mathrm{C}$ (Hijmans et al., 2005). Forests are assigned to Moist Central Africa (Fayolle et al., 2014) and were originally described as a transition type between lowland evergreen and semi-evergreen forests (Letouzey, 1985). In this area, local populations mainly comprise Bantu people, whereas the Baka Pygmy people constitute another smaller ethnolinguistic group. The Baka are considered as the Indigenous population, who were present in the forest even before the arrival of Bantu people (Winterbottom, 1992). Among the Bantu, three ethnolinguistic groups are considered native to the study area: Badjoué, Nzimé, and Ndjem. These are all part of the Makaa-Ndjem ethnolinguistic group, corresponding to the coded Zone A80 in the Guthrie classification of languages (Guthrie, 1948). They pursue similar production systems: shifting cultivation, hunting, fishing, and gathering of forest products (Vermeulen, 2000). We define "local populations" as rural communities depending on the forests for their daily activities (Bantu and Baka Pygmy populations), and "forest stakeholders" as all members of the forestry sector (comprising local populations as well as managers, workers, or officials).

According to the World Resources Institute (2012), the classified area of the National Forest Estate (NFE) represented 37\% (17.5 million hectares) of Cameroon in 2011. We worked in specific locations (Fig. 1) associated with the three major land allocation types of Cameroonian tropical forests: (i) protected areas ( $42 \%$ of the NFE); (ii) logging concessions divided in forest management units (FMUs, $40 \%$ of the NFE); and (iii) community forests ( $6 \%$ of the NFE), representing in total $88 \%$ of the NFE. These forest land allocation types are also largely represented in Central Africa, at the regional scale. Estimated area, mean forest cover, deforestation rate, and the legal and illegal activities in each land allocation type are mentioned in the Supplementary Information (Appendix A).

(i) The protected area studied was the Dja Biosphere Reserve, which is the largest protected area in the country and aims to conserve biodiversity according to a management plan approved by the Forestry Administration. It is a "Man and Biosphere Reserve" since 1981, listed as a UNESCO World Heritage site since 1987, and is defined as the IV-category of IUCN protected areas. The reserve comprises a core area of nearly 526,000 hectares in which agricultural, gathering and hunting activities are prohibited. In the buffer zone (not yet precisely delimited), local populations can pursue non-industrial sustainable activities such as wood collection, NTFP gathering, and slash-and-burn agriculture (Appendix A). According to the Conservation Service and local guides, between 15 and 100 tourists annually visit the northern part of the reserve where this research was conducted. Tourists are interested in discovering local Baka traditions and major wildlife species such as forest buffalo (Syncerus caffer nanus), chimpanzee (Pan troglodytes), giant pangolin (Manis gigantea), elephant (Loxodonta cyclotis), mantled guereza (Colobus guereza), leopard (Panthera pardus), or western lowland gorilla (Gorilla gorilla gorilla). This area is also included in the Dja Biosphere Regional REDD + Project, which aims to reduce deforestation and forest degradation on 1.2 million hectares of forests in and around the protected area. Previous awareness campaigns for wildlife conservation were conducted under the European "ECOFAC" program.

(ii) The logging concession studied was certified by the Forest Stewardship Council (FSC) in 2008, and has been managed by the Pallisco company (http://www.pallisco-cifm.com) since 2004. The company develops forest management plans for their concession areas with a 30-year planning approved by the Forestry Administration (Cellule Aménagement Pallisco and Nature+, 2015). The main timber species selectively logged are sapelli (Entandrophragma cylindricum), tali (Erythrophleum suaveolens), okan (Cylicodiscus gabunensis), and ayous (Triplochiton scleroxylon). Nearly 341,000 hectares of the Pallisco logging concession are FSC-certified, with FSC standards applied to ensure economic effectiveness and viability of forest management; ecological integrity of the forests (i.e., reduced-impact logging, protection against pollution, protection of wildlife); and social equity. The social program includes a supply of complete security equipment, health care, accommodation, social security cover, and training for workers. The bordering rural populations are also supported through the Area Fee distributed to local councils, communication and education, creation of a consultation framework, and social realizations such as housing improvement, construction of water wells, boreholes, and classrooms or donation of school supplies. There is no tourist activity in the logging concession. Local populations benefit from user rights for NTFP and deadwood collection in $98 \%$ of the concession area, and hunting activities are authorized for self-consumption, with traditional selective techniques, and only for non-protected species (see details in Appendix A).

(iii) The three community forests (CF) that we studied - Medjoh (4964 ha), Avilso (3433 ha), and Eschiambor (5069 ha) - are located between the protected area and the logging concession. The CF were created in the country after the 1994 Cameroonian Forestry Law with the objective of improving rural livelihoods by increasing monetary revenues, village infrastructures, forest selfmanagement empowerment, and rural employment (Ezzine de Blas et al., 2011). CF are dedicated to exclusive use by village communities (i.e., for timber harvesting, hunting, NTFP gathering, deadwood collection, or agriculture). They are managed with a simple management plan written and implemented by the community itself, after the approval and under the control of the Forestry Administration.

\subsection{Sampling strategy}

We interviewed a total of 225 respondents, distributed into three groups of 75 forest stakeholders, with each group being interviewed about one of the three land allocation types. We used stratified sampling to divide each group of 75 respondents among several sampling locations, with a total of 23 locations for the 225 respondents. In each sampling location, respondents were selected randomly and the number of selected respondents was proportional to the total population of the location. The 23 different locations were situated inside or beside (up to $4.1 \mathrm{~km}$ ) one of the three land allocation types: (i) nine villages in the buffer zone of the protected area; (ii) four villages bordering the logging concession, the workers' camp, and the headquarters of the company; and (iii) eight villages located inside the three community forests (Fig. 1). These locations covered more than $50 \%$ of all possible survey locations.

The total sample size of 225 was based on an estimation of the minimal number of respondents needed $(n)$ to reach a statistical 
accuracy of $5 \%(d)$ for estimating the proportion of positive answers $(p)$ concerning each ES perception, calculated with the following formula: $n=4 p(1-p) / d^{2}$ (Dagnelie, 2011). Based on the answers provided by the first 20 respondents interviewed ( $p$ ), we estimated the total sample size needed $(n)$ to reach the statistical accuracy of $5 \%(d)$ for estimating the proportion of positive answers for each individual ES perception. We used the minimum value obtained to define our real sample size of 225 respondents. Based on the final dataset of individual ES perceptions $(p)$, we confirmed that the sample size of 225 respondents ( $n$ ) was sufficient to reach a statistical accuracy of $5 \%(d)$.

\subsection{Questionnaire survey}

In order to evaluate the ES perceptions of forest stakeholders, we used a questionnaire survey conducted face to face with the 225 respondents. The questionnaire survey was conducted on a voluntary basis after the investigator explained the aim of the study with a systematic statement. Respondents gave their free, prior, and informed verbal consent for participation. Our methodology followed the recommendations of Bird (2009). Three groups of 75 respondents each were attributed to three distinct land allocation types. All questions were asked explicitly with respect to the forest land allocation type attributed to the respondent. Respondents were well aware of the limits of each forest land allocation type and these limits are clearly and physically materialized with painted trees and well-maintained paths. The questionnaire survey was divided into two sections to collect information about two distinct types of ES perceptions (Table 1): First, a general, open-ended question was asked to identify the spontaneous perceptions of ES significance: "What are the usefulness and interests of this forest for local populations?" Second, 16 directed questions allowed evaluation of the perceptions of ES abundance for 16 particular
ES. Respondents were encouraged to justify their answers with a short explanation. The 16 ES were grouped into provisioning ES, regulating ES, and cultural \& amenity ES according to the standard classification of The Economics of Ecosystems and Biodiversity (de Groot et al., 2010b). The 16 questions were asked in random order to avoid any influence among provisioning, regulating, and cultural \& amenity ES perceptions. Selection of the $16 \mathrm{ES}$ included in the directed questions was based on a combination of different lists of ES provided by tropical forests (Brandon, 2014; de Groot et al., 2002; Fenton, 2012). The term "ecosystem services" was not explicitly used during the survey, but rather the concrete benefits that people directly get from forests were mentioned (Orenstein and Groner, 2014). The questionnaire was tested with 10 local experts (scientists and officials) before conducting the survey.

The questionnaire survey was carried out by the same investigator between March and May 2016. Questions and answers were in French for 210 respondents (one of the two national official languages of Cameroon, the other being English) and with the assistance of a translator in the Baka language for 15 respondents. The investigator was trained to conduct and deliver the questionnaire to avoid any differences in data collection, as recommended by Collins (2003). Individual surveys lasted between 15 and 45 minutes. The investigator took notes and did not use any recorder. If our methodology was scaled up with more respondents and several investigators, use of audio recording instead of note-taking would have been recommended to avoid any bias between investigators, as well as a unique translator if possible.

\subsection{Data analysis}

The answers obtained from the two sections of the questionnaire survey (one open-ended question and 16 directed questions) were

Table 1

Classification questions asked to the 225 respondents and the two-section questionnaire survey used for the evaluation of ecosystem services (ES) perceptions. (A) The first section of the questionnaire was a general open-ended question for the evaluation of ES significance, and (B) the second section comprised 16 directed questions for evaluating the perceptions of ES abundance, corresponding to a set of $16 \mathrm{ES}$ provided by tropical forests and grouped into: provisioning ES ( $\mathrm{n}=6$ ), regulating ES $(n=5)$, and cultural \& amenity ES $(n=5)$. The service "Vegetal NTFP" gathers the provision of all vegetal non-timber forest products coming from the forest (wild fruits, leaves, tubers, mushrooms, raw materials, etc.), except traditional medicine which has been evaluated separately.

\begin{tabular}{|c|c|c|}
\hline \multicolumn{3}{|c|}{ Classification questions: } \\
\hline & \multicolumn{2}{|l|}{ Gender? } \\
\hline & \multicolumn{2}{|l|}{ Age? } \\
\hline & \multicolumn{2}{|l|}{ Ethnicity? } \\
\hline & \multicolumn{2}{|l|}{ Main occupation? } \\
\hline \multicolumn{3}{|c|}{ A) Open-ended question (perceptions of ES significance): } \\
\hline & \multicolumn{2}{|c|}{ "What are the usefulness and interests of this forest for local populations?" } \\
\hline \multicolumn{3}{|c|}{ B) Directed questions (perceptions of ES abundance): } \\
\hline \multirow[t]{3}{*}{$\begin{array}{l}\text { Categories of } \\
\text { ES }\end{array}$} & Ecosystem services & Questions ("Yes/No? Please explain...") \\
\hline & Meat (hunting) & "Is there a lot of meat coming from hunting in this forest?" \\
\hline & Fish (fishing) & "Is there a lot of fish coming from fishing in this forest?" \\
\hline \multirow{4}{*}{$\begin{array}{l}\text { Provisioning ES } \\
(\mathrm{n}=6)\end{array}$} & Vegetal NTFP & "Are there a lot of vegetal non-timber forest products coming from gathering in this forest?" \\
\hline & Traditional medicine & "Is there a lot of traditional medicine coming from this forest?" \\
\hline & Timber & "Do local populations find a lot of timber coming from this forest?" \\
\hline & Firewood & "Do local populations find a lot of firewood coming from this forest?" \\
\hline \multirow{5}{*}{$\begin{array}{l}\text { Regulating ES } \\
(n=5)\end{array}$} & Climate regulation & "Does this forest influence the climate? If all of this forest is cut, would the climate and seasons be different?" \\
\hline & Water quality regulation & "Is the water quality better in the rivers of this forest than outside?" \\
\hline & Air quality regulation & "Is the air quality better in this forest than outside?" \\
\hline & $\begin{array}{l}\text { Soil formation and } \\
\text { regeneration }\end{array}$ & "Is the soil fertility better in this forest than outside for slash-and-burn practices?" \\
\hline & Natural hazard mitigation & "Does this forest protect the population against disturbances, as storms, floods or diseases?" \\
\hline \multirow{5}{*}{$\begin{array}{l}\text { Cultural \& } \\
\text { amenity ES } \\
(n=5)\end{array}$} & Cultural heritage and identity & "Is this forest part of the heritage of local populations? Does it have a symbolic value?" \\
\hline & Inspiration for culture & "Is it possible to see many plants, trees, animals, and insects in this forest?" \\
\hline & Spiritual experience & "Are there a lot of rituals and traditions in this forest?" \\
\hline & Recreation & "Do local populations sometimes go inside this forest to relax and stroll without working?" \\
\hline & Tourism & "Are there a lot of tourists coming in this forest and paying something to come?" \\
\hline
\end{tabular}


considered as two independent datasets coded in binary values. They were office-coded from the week after the last questionnaire conducted (Bird, 2009). A list of all forest ES identified in the open-ended answers (first section of the questionnaire, perceptions of ES significance) was compiled. The open-ended answer of each respondent was then coded as a list of binary values: we attributed the value "1" to each ES identified in the answer of the respondent, and the value "0" to each ES not identified. Answers to the 16 directed questions (second section of the questionnaire, perceptions of ES abundance) were also coded as 16 binary values: "0" values were attributed to ES perceived as "not provided" or "less provided than before", and " 1 " values were attributed to ES perceived as "clearly provided".

The most frequently reported ES provided by forests to local populations were identified using both answer datasets ( $R$ package "ggplot2", Wickam, 2009). In each of the two datasets, we calculated the proportions of respondents identifying each ES individually, and identifying at least one ES out of the three ES categories (provisioning, regulating, and cultural \& amenity ES).

In order to identify the effect of spatial and socio-demographic variables as potential determinants of the perceptions of ES abundance, we used 16 logistic regressions modelling the probability of positive answers for each individual ES (second section of the questionnaire) as a function of the six following variables: (i) the land allocation type considered in the answers (spatial qualitative variable), (ii) the deforestation rate between 2000 and 2012 around the sampling locations (spatial quantitative variable), (iii) gender (socio-demographic qualitative variable), (iv) age (socio-demographic quantitative variable), (v) ethnicity (socio-demographic qualitative variable), and (vi) the main occupation of each respondent (socio-demographic qualitative variable). $P$-values were adjusted with the Benjamini and Hochberg (1995) method to account for multiple comparisons, controlling the false discovery rate. For each significant qualitative variable explaining the perception of a service, we computed confidence intervals on the differences among the means of levels of the variable with Tukey's 'Honest Significant Differences' method (level of significance: $P<0.05$ ), based on an analysis of variance model. For each significant quantitative variable (deforestation rate and age of respondents) explaining the perception of a service, we confirmed their significance in shaping the ES perceptions with Pearson's correlation tests.

The deforestation rate (Fig. 1C) used in the previous analysis was calculated in a circle of radius $2 \mathrm{~km}$ centered on each sampling location, using the 30-meters spatial resolution data of net tree cover loss between 2000 and 2012 (Hansen et al., 2013). The calculated deforestation rates around the sampling locations were used to quantify the impacts of the direct surrounding environment of the respondents on their perceptions of ES, more than the deforestation in overall land allocation types. We chose a radius of $2 \mathrm{~km}$ for calculating the deforestation rates in order to avoid overlaps of calculated deforestation between adjacent sampling locations, and based on the mean distance of $2.2 \mathrm{~km}$ to access the collection sites of NTFPs from the center of the largest village in the study area (Gillet et al., 2016). Mertens and Lambin (1997) also observed that more than $80 \%$ of all deforestation occurred at a distance less than $2.5 \mathrm{~km}$ from main roads in southern Cameroon.

\section{Results and discussion}

\subsection{Characteristics of respondents}

Despite our random sampling, more men (78\% of respondents) were interviewed because women were less willing to participate when asked to. Indeed, as in many traditional African societies, household heads are usually men, which potentially affects the willingness for women to express their opinion (Dave et al., 2016). However, the sex ratio of respondents was similar among the three land allocation types. Respondents were between 15 and 79 years old, the mean age was 43 .
Respondents were divided into six ethnolinguistic groups: Badjoué (43\% of respondents), Nzimé (18\%), Ndjem (3\%), Baka Pygmy (7\%), non-local Cameroonians (25\%), and foreigners (4\%, corresponding to students and expatriates working in the logging concession). The main occupations of the respondents were: farmers ( $37 \%$ of respondents), salaried (29\%), mixed occupation (19\%, comprising respondents who acknowledged having more than one occupation), students (6\%), officials $(4 \%)$, fishermen $(1 \%)$, hunters $(1 \%)$, and others $(3 \%$, comprising merchants, tour guides, and taxi men). The characteristics of the 225 respondents match the socio-economic surveys conducted by the logging concession (Cellule Aménagement Pallisco and Nature +, 2015), and the respondents can be considered as representative of local communities and forest stakeholders in the study area. Additional details about the sampled population are provided in the Supplementary Information (Appendix B).

\subsection{Perceptions of ES significance and abundance}

We compiled a list of 17 ES mentioned in the open-ended answers (first section of the questionnaire, perceptions of ES significance). Only three differences were observed with the list of 16 ES used in the directed questions (second section of the questionnaire, perceptions of ES abundance): firewood and timber were combined as "wood", and two supplementary cultural ES were identified (education and housing). When analyzing the ES reported most frequently, spontaneous (ES significance) and directed perceptions (ES abundance) showed different results (Fig. 2).

Perceptions of ES significance mainly comprised provisioning (93.3\% of respondents) and cultural \& amenity (68.0\%) ES (spontaneous perceptions, Fig. 2A). In contrast, regulating services were much less frequently mentioned (16.0\%), and were almost exclusively mentioned in the protected area $(33.3 \%$ of respondents from the protected area, $10.7 \%$ from the logging concession, and $4.0 \%$ from the community forests). This result highlights the influence of past awareness campaigns on spontaneous ES perceptions, as also shown by other authors (e.g., Hartter and Goldman (2011) in Uganda). This supports the possible appropriation of future conservation programs by local populations based on environmental education (Caballero-Serrano et al., 2017), raising awareness of the benefits and provision of ES (Bryan et al., 2010), and explanation of the law (Vermeulen et al., 2009). In the protected area, $93.3 \%$ of respondents identified at least one cultural \& amenity ES, compared to $57.3 \%$ in the community forests and $53.3 \%$ in the logging concession. The most frequently perceived ES were: vegetal non-timber forest products provision ( $83.6 \%$ of all respondents), meat provision $(59.6 \%)$, cultural heritage $(50.2 \%)$, fish provision $(36.0 \%)$, wood provision (34.7\%), and traditional medicine provision $(30.2 \%)$.

Provisioning services were also the most frequently perceived ES in other studies such as Hartter (2010) in Uganda, Zhang et al. (2016) in Nigeria, or Dave et al. (2016) in Madagascar. The perceptions of provisioning services from the forest were also analyzed by Sassen and Jum (2007) in central Cameroon, who showed high dependency of farmers on the forest for their livelihoods. In a subsistence economy based on the primary sector, particularly in developing countries, provisioning services are considered as the most important (Iftekhar and Takama, 2007), associated with more tangible and identifiable value (Rodríguez et al., 2006), and being fundamental for the livelihoods of local populations (Fagerholm et al., 2012). Therefore, provisioning ES are also more frequently assessed than other categories (e.g., Guerbois and Fritz (2017) in Zimbabwe). But, our results also show that forest stakeholders were aware of the abundant supply of all regulating ES when explicitly questioned about them using directed questions.

All respondents identified the abundance of at least one provisioning and one regulating ES, and in most cases (99.6\%), at least one cultural \& amenity ES as well (directed perceptions, Fig. 2B). The abundant ES most frequently identified from the 16 directed questions were: provision of traditional medicine ( $97.3 \%$ of all respondents), 
A

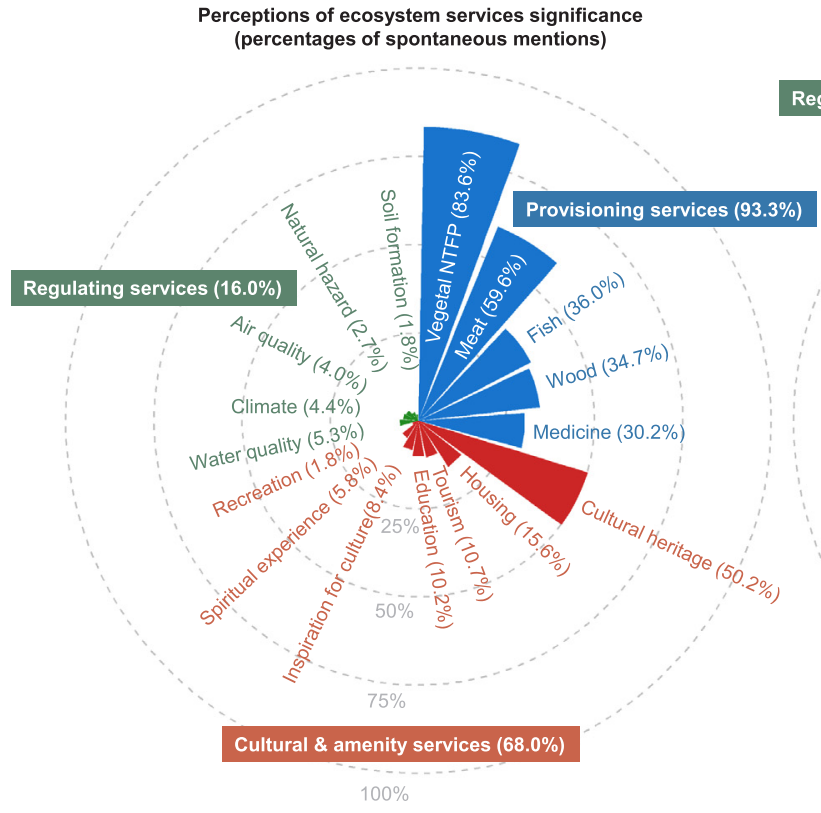

B

Perceptions of ecosystem services abundance (percentages of directed mentions)

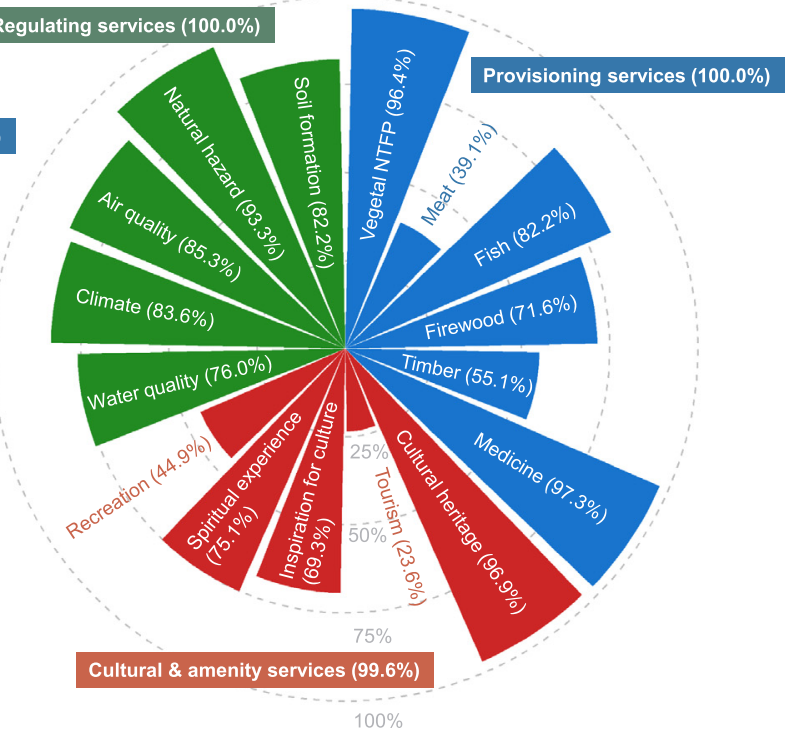

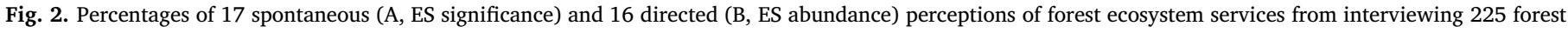

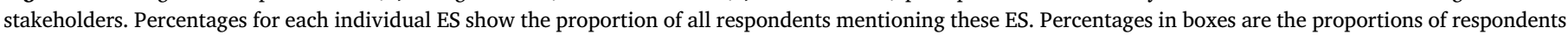

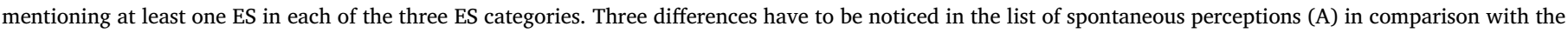

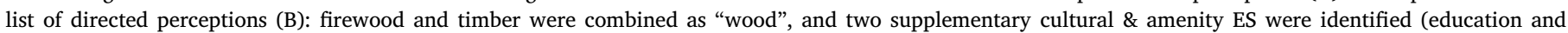
housing).

cultural heritage (96.9\%), provision of vegetal non-timber forest products $(96.4 \%)$, natural hazard mitigation (93.3\%), air quality regulation $(85.3 \%)$, climate regulation $(83.6 \%)$, fish provision $(82.2 \%)$, soil formation and regeneration (82.2\%), water quality regulation (76.0\%), spiritual experience $(75.1 \%)$, firewood provision $(71.6 \%)$, and inspiration for culture $(69.3 \%)$.

The existing scientific literature is not unanimous concerning the interpretation of relative frequencies of perceptions on provisioning, regulating, and cultural ES. Some authors argue that rural populations perceive provisioning ES more frequently than in urban societies, due to a cognitive disconnection of human well-being from life supporting environments in cities (e.g., Casado-Arzuaga et al., 2013; Martín-López et al., 2012). Others emphasize that rural residents mention regulating and cultural ES more frequently than provisioning ES, because they possess ecological knowledge of the importance of the environment and the forests' ES (e.g., Muhamad et al., 2014). Our results showed that, depending on the method used (evaluation of spontaneous or directed perceptions), both these hypotheses could be confirmed.

Logically, perceptions of ES abundance included more frequent mentions of all individual ES than spontaneous ES significance, with the exception of meat provision. This implies that according to forest stakeholders' perceptions, meat abundance could not be sufficient to meet its high significance for local populations. However, the perceptions of meat significance and abundance must be interpreted critically and are most probably underestimated. Indeed, hunting practices are prohibited or at least regulated in the three land allocation types (see Appendix A), potentially leading to false answers of respondents wanting to conceal their knowledge of hunting practices, particularly in the protected area and the logging concession. Respondents were possibly inhibited by the fear of controls and repression by the investigator, despite being an independent researcher. Gillet et al. (2016) noticed particularly high hunting pressure in this area. Hunting practices target a wide range of animal species, of varying sizes from large mammals to very small rodents in highly defaunated areas. Commercial hunting has also been recognized as a major threat in the Dja Reserve (Betti, 2004), and the conservation effectiveness of this protected area has been questioned. Moreover, accessible forests such as community forests are known to be strongly defaunated and could be considered as "empty forests" (Nasi et al., 2011), thus inducing major ecological consequences.

\subsection{Determinants of perceptions of ES abundance}

Slight variations in the perceptions of ES abundance were identified. Nevertheless, we used logistic regressions to identify their spatial or social determinants. The two spatial variables "land allocation type" and "deforestation rate" significantly influenced the perceptions of the abundance of five and two individual ES. The four socio-demographic variables had fewer impacts (Table 2): "gender," "age," "ethnicity," and "main occupation" each significantly influenced the perceptions of one individual ES. Prior to this analysis, we removed two categories of "main occupation" from the dataset as they were each only represented by two respondents ("fishermen" and "hunters"). The adjusted $P$-values associated with the explaining variables of 16 logistic regressions are provided in the Supplementary Information (Appendix C).

Perceptions of the five ES abundances significantly influenced by land allocation type were firewood, tourism, inspiration for culture, timber, and spiritual experience in decreasing order of significance. The protected area showed the most frequent mentions of two ES: inspiration for culture and tourism. The logging concession showed the most frequent mentions of one ES: spiritual experience (linked to the respect that local populations maintain for ancient villages mainly situated in the logging concession far from main roads and considered as sacred sites). The community forests showed the most frequent mentions of two ES: firewood and timber provision. Apart from these particular ES, perceptions of individual ES abundance did not differ among the three studied land allocation types. This implies that these forests present rather similar potentials in their ES supply, which is also explained by comparable forest covers: from $89.5 \%$ in the buffer zone of the protected area to $90.9 \%$ in the agroforestry zone of the logging concession 
Table 2

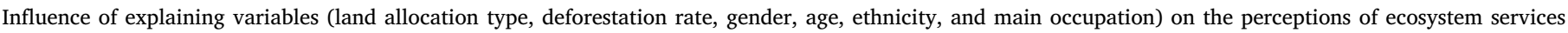

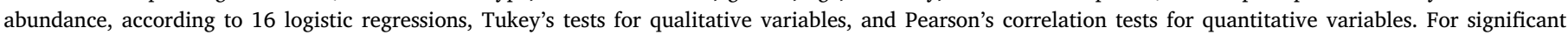

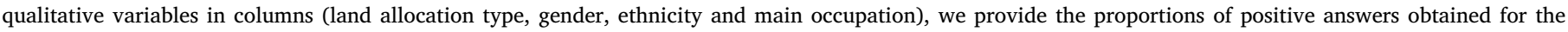

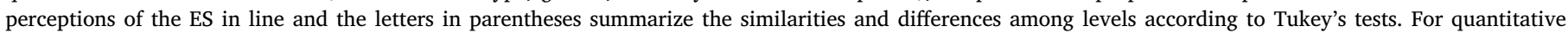

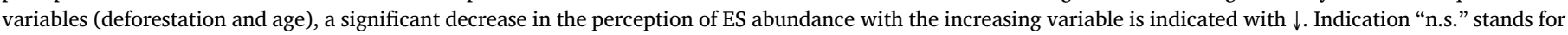
"not significant" influence of the variable in the column on ES perceptions in line.

\begin{tabular}{|c|c|c|c|c|c|c|c|c|c|c|c|c|c|c|c|c|c|c|}
\hline \multirow[b]{2}{*}{ Services } & \multicolumn{3}{|c|}{$\begin{array}{c}\text { Land allocation } \\
\text { type }\end{array}$} & \multirow{2}{*}{ 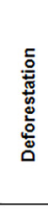 } & Gender & \multirow[b]{2}{*}{$\stackrel{g}{<}$} & \multicolumn{6}{|c|}{ Ethnicity } & \multicolumn{6}{|c|}{ Main occupation } \\
\hline & 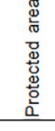 & 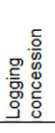 & 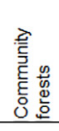 & & 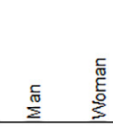 & & 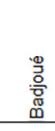 & $\frac{\mathscr{E}}{\mathrm{N}}$ & $\begin{array}{l}\frac{E}{0} \\
\frac{\Phi}{\bar{z}} \\
\end{array}$ & 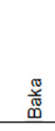 & 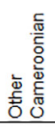 & 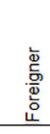 & 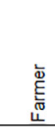 & 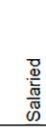 & $\begin{array}{l}\vec{J} \\
\frac{x}{\Sigma} \\
\end{array}$ & $\begin{array}{l}\frac{\bar{w}}{\underline{\underline{u}}} \\
\text { O } \\
\end{array}$ & 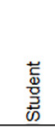 & 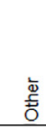 \\
\hline Vegetal NTFP & \multicolumn{3}{|c|}{ n.s. } & n.s. & n.s. & n.s. & \multicolumn{6}{|c|}{ n.s. } & \multicolumn{6}{|c|}{ n.s. } \\
\hline Meat (hunting) & \multicolumn{3}{|c|}{ n.s. } & n.s. & n.s. & n.s. & \multicolumn{6}{|c|}{ n.s. } & $\begin{array}{l}36 \% \\
(\mathrm{ab})\end{array}$ & $\begin{array}{l}52 \% \\
\text { (b) }\end{array}$ & $\begin{array}{l}16 \% \\
\text { (a) }\end{array}$ & $\begin{array}{l}0 \% \\
\text { (a) }\end{array}$ & $\begin{array}{l}69 \% \\
\text { (b) }\end{array}$ & $\begin{array}{l}67 \% \\
\text { (ab) }\end{array}$ \\
\hline Fish (fishing) & \multicolumn{3}{|c|}{ n.s. } & n.s. & n.s. & n.s. & \multicolumn{6}{|c|}{ n.s. } & \multicolumn{6}{|c|}{ n.s. } \\
\hline Firewood & $\begin{array}{l}52 \% \\
\text { (a) }\end{array}$ & $\begin{array}{l}61 \% \\
\text { (a) }\end{array}$ & $\begin{array}{c}100 \% \\
\text { (b) }\end{array}$ & $\downarrow$ & n.s. & n.s. & \multicolumn{6}{|c|}{ n.s. } & \multicolumn{6}{|c|}{ n.s. } \\
\hline Timber & $\begin{array}{l}53 \% \\
(\mathrm{ab})\end{array}$ & $\begin{array}{l}43 \% \\
\text { (a) }\end{array}$ & $\begin{array}{l}67 \% \\
\text { (b) }\end{array}$ & $\downarrow$ & $\begin{array}{cc}49 \% & 74 \% \\
\text { (a) } & \text { (b) }\end{array}$ & n.s. & \multicolumn{6}{|c|}{ n.s. } & \multicolumn{6}{|c|}{ n.s. } \\
\hline Traditional medicine & \multicolumn{3}{|c|}{ n.s. } & n.s. & n.s. & n.s. & \multicolumn{6}{|c|}{ n.s. } & \multicolumn{6}{|c|}{ n.s. } \\
\hline Cultural heritage and identity & \multicolumn{3}{|c|}{ n.s. } & n.s. & n.s. & n.s. & \multicolumn{6}{|c|}{ n.s. } & \multicolumn{6}{|c|}{ n.s. } \\
\hline Tourism & $\begin{array}{l}64 \% \\
\text { (b) }\end{array}$ & $\begin{array}{l}1 \% \\
\text { (a) }\end{array}$ & $\begin{array}{l}5 \% \\
\text { (a) }\end{array}$ & n.s. & n.s. & n.s. & \multicolumn{6}{|c|}{ n.s. } & \multicolumn{6}{|c|}{ n.s. } \\
\hline Inspiration for culture & $\begin{array}{l}93 \% \\
(c)\end{array}$ & $\begin{array}{l}71 \% \\
\text { (b) }\end{array}$ & $\begin{array}{l}44 \% \\
\text { (a) }\end{array}$ & n.s. & n.s. & $\downarrow$ & & & $n$ & & & & & & & & & \\
\hline Spiritual experience & $\begin{array}{l}78 \% \\
\text { (ab) }\end{array}$ & $\begin{array}{c}84 \% \\
\text { (b) }\end{array}$ & $\begin{array}{l}63 \% \\
\text { (a) }\end{array}$ & n.s. & n.s. & n.s. & & & $n$ & & & & & & & & & \\
\hline Recreation & & n.s. & & n.s. & n.s. & n.s. & & & $n$ & & & & & & & & & \\
\hline Water quality regulation & & n.s. & & n.s. & n.s. & n.s. & $\begin{array}{c}88 \% \\
\text { (b) }\end{array}$ & $\begin{array}{c}58 \% \\
\text { (a) }\end{array}$ & $\begin{array}{l}50 \% \\
(\mathrm{ab}) \\
\end{array}$ & $\begin{array}{l}93 \% \\
(\mathrm{ab}) \\
\end{array}$ & $\begin{array}{c}68 \% \\
\text { (a) }\end{array}$ & $\begin{array}{l}60 \% \\
(\mathrm{ab}) \\
\end{array}$ & & & & & & \\
\hline Climate regulation & & n.s. & & n.s. & n.s. & n.s. & & & $n$ & & & & & & & & & \\
\hline Air quality regulation & & n.s. & & n.s. & n.s. & n.s. & & & $n$ & & & & & & & & & \\
\hline Natural hazard mitigation & & n.s. & & n.s. & n.s. & n.s. & & & $n$ & & & & & & & & & \\
\hline Soil formation and regeneration & & n.s. & & n.s. & n.s. & n.s. & & & & & & & & & & & & \\
\hline
\end{tabular}

(Appendix A). We could then expect to observe more distinct differences in the perceptions of ES abundance in comparison with other land uses, such as mining concessions or agricultural areas. The respondents from areas that experienced the highest deforestation rates between 2000 and 2012 perceived the abundance of timber and firewood less frequently (58 respondents were interviewed in areas with more than $5 \%$ of deforestation). The net deforestation rates for the period 2000-2012 in a radius of $2 \mathrm{~km}$ from the sampling locations were between $0.0 \%$ and $12.7 \%$ (Hansen et al., 2013), with the following means for sampling locations grouped by land allocation types: $0.5 \%$ for the protected area, $5.0 \%$ for the logging concession, and $3.1 \%$ for the community forests. The net deforestation rates estimated in close vicinity $(2 \mathrm{~km})$ of the respondents were independent of the net deforestation rates inside each whole land allocation type, which were: $0.0 \%$ in the protected area (core area), $0.1 \%$ in the logging concession, and $1.5 \%$ in the community forests for the same period (see Appendix A for more details). Several authors have already shown the influence of spatial variables in shaping ES perceptions, highlighting the role of the interview location (Cuni-Sanchez et al., 2016; Hartter et al., 2014), local landscape (Alassaf et al., 2014; Allendorf and Yang, 2013; Muhamad et al., 2014; Zhang et al., 2016), vicinity and access to forest resources (Castillo et al., 2005; Diaz et al., 2011; Sodhi et al., 2010), and the use (or non-use) of particular areas in the landscape (Alassaf et al., 2014; Allendorf and Yang, 2013; Muhamad et al., 2014).

Women perceived the abundance of timber more frequently than men. The cultural inspiration from the forest was less frequent for older respondents. Cultural inspiration was evaluated with a question about the richness of all species in the forest (or biodiversity), suggesting that older respondents currently perceive the existence of less species in forests than in the past. The ethnicity of the respondents significantly explained the perceptions of water quality regulation: Badjoué respondents mentioned the role of the forest in water quality regulation more frequently than the Nzimé and non-native Cameroonian respondents. Respondents with different occupations showed distinct perceptions of the supply of bushmeat through hunting: salaried and students perceived a high abundance of meat more frequently than the officials and respondents with mixed occupations. Socio-demographic variables were only rarely observed as determinants of ES perceptions in our study in southeastern Cameroon, in contrast with other studies. For example, socioeconomic status (Alassaf et al., 2014; Allendorf and Yang, 2013; Caballero-Serrano et al., 2017; Hartter et al., 2014; Muhamad et al., 2014; Orenstein and Groner, 2014), education level (Allendorf and Yang, 2013; Sodhi et al., 2010), age (Allendorf and Yang, 2013; Martín-López et al., 2012), gender (Allendorf and Yang, 2013; Hartter, 2010; Orenstein and Groner, 2014; Rönnbäck et al., 2007; Warren-Rhodes et al., 2011), social conditioning (Zhang et al., 2016), life experience and historic relationships with the environment (Alassaf et al., 2014; Allendorf and Yang, 2013; Caballero-Serrano et al., 2017; Muhamad et al., 2014; Zhang et al., 2016) were highlighted as important determinants of ES perceptions in other contexts. The importance of certain socio-demographic variables as determinants of ES perceptions in other studies clearly shows that ES perceptions are highly dependent on the local socio-cultural context (Alassaf et al., 2014; Allendorf and Yang, 2013; Caballero-Serrano et al., 2017; Hartter et al., 2014; Muhamad et al., 2014; Orenstein and Groner, 2014), notably defined by land tenure and village territory size in Central Africa (Gillet et al., 2016, 2015).

The perceptions of the abundance of nine ES (out of 16) were not explained by any of the six spatial or socio-demographic variables (Table 2). Our hypothesis of variations in ES abundance among contrasting forest land allocation types led us to conduct a spatial stratified sampling. Although our results showed relative homogeneity of ES perceptions through the area, it is still difficult to disentangle the major effects between social and spatial determinants because of unbalanced 
social sampling (see Appendix B).

\subsection{Need for an integrated ES assessment}

While ES have already been investigated in other regions of Africa (e.g., Byg et al., 2017; Dawson and Martin, 2015; Hartter and Goldman, 2011), our study was the first step in integrated local-scale assessment of multiple ES provided by forests in Central Africa. We used a social approach to consider the perceptions of ES significance and abundance before implementing the more frequent ecological and economic approaches (Boeraeve et al., 2015; Cuni-Sanchez et al., 2016; Kremen and Ostfeld, 2005; Martín-López et al., 2014; Satz et al., 2013; Spangenberg and Settele, 2010).

The local forest stakeholders must inevitably be integrated in ES assessments as they are daily using, managing, and changing these ecosystems (Muhamad et al., 2014). A social approach in ES assessment could not be replaced by a unique economic valuation. Indeed, monetary proxies overlook the non-material benefits provided by ecosystems (Dawson and Martin, 2015). These benefits can be the basis for interpreting the ES perceptions obtained from social approaches, such as considering the importance of spiritual experience in the logging concession in our study.

As a priority, we recommend gaining further insights on the unique ES for which the perceptions of abundance do not meet the ES significance, i.e., bushmeat provision. This is essential for any policy ambitions for the maintenance of ES supply and sustainable management (Geijzendorffer and Roche, 2014). We also propose to quantify the most variable (and controversial) ES in terms of perceptions of abundance such as recreation, tourism, timber provision, spiritual experience, firewood provision, meat provision, water quality regulation, and inspiration for culture (biodiversity), using complementary assessment methods. The supply of all of these ES should be quantified with detailed monitoring, integrating spatial and temporal variability, using market surveys for provisioning ES (Levang et al., 2015), social mapping for cultural ES (Fagerholm et al., 2012), and ecological measures for regulating ES (Mononen et al., 2017).

Our study could be replicated and integrated at a larger scale across Central African forests and countries. We acknowledge that no one should directly extrapolate our results to the entire Central African region or even to other communities. Although only slight variations were observed among ES perceptions in contrasting forest land allocation types, over-simplifying complex socio-ecosystems across large scales could lead to a lack of policy relevance of interpretations and decisions. Local studies of people's uses and preferences are essential for a proper understanding of social-ecological systems (Dawson and Martin, 2015). Qualitative assessments of ES provision are also required to implement sustainable management strategies and decisions (Braat and de Groot, 2012; Collins et al., 2010).

\subsection{Practical implications for management}

We indicate three concrete recommendations for forest management based on our results.

First, bushmeat provision appeared to be the most deficient in the perceptions of ES abundance, compared to ES significance. In Central Africa, both biodiversity conservation and human food security must be pursued through multiple compatible interventions (Friant et al., 2015; Lindsey et al., 2013). Law enforcement is indispensable to mitigate illegal poaching (Critchlow et al., 2017; Lindsey et al., 2013) but a complete ban is not conceivable for poor households heavily dependent on bushmeat as their main source of proteins (Challender and MacMillan, 2014; Foerster et al., 2012; Lindsey et al., 2013). We suggest implementing participatory repressive enforcement program in the logging concession, targeting the poaching businesses with the participation of local populations (Vermeulen et al., 2009). We also highlight the importance of distinguishing endangered species (such as great apes) that must not be hunted, and more resilient species, such as the blue duiker (Philantomba monticola) or the African brush-tailed porcupine (Atherurus africanus), that could sustain moderate hunting pressure (Nasi et al., 2011; van Vliet and Nasi, 2008). Even if factors such as taste preference or tradition may influence human dietary choices (Ordaz-Németh et al., 2017), we also recommend providing alternative sources of proteins, for instance through local fish farming, local aviculture, or supply of butcher's meat in a small grocery equipped with a freezer. Any adequate domestic fishery or animal rearing system needs to minimize negative environmental impacts (Lindsey et al., 2013; Rentsch and Damon, 2013; Wilkie et al., 2005), and offer products at affordable prices for poor rural populations. Cultural appropriation of alternative sources of proteins could also be critical, considering the mental blocks for rearing activities in Central Africa. Use of vegetal proteins such as beans and other pulses (Ordaz-Németh et al., 2017), and edible insects (particularly caterpillars) that are highly consumed in Cameroon (Meutchieye et al., 2016) should also be considered and expanded as alternative sources of proteins.

Second, considering the perceptions of high abundance of NTFP ( $96.4 \%$ of respondents), this economic sector shows a high potential as an alternative livelihood for the future. In Cameroon, NTFP are an important source of food (Sassen and Jum, 2007) and income for households (Lescuyer, 2010). Domestication of NTFP species for agroforestry systems have shown potential to improve livelihoods (Ingram et al., 2012; Vermeulen and Fankap, 2001). Endamana et al. (2016) identified the following NTFP as the most important sources of cash income in Cameroon, Congo, and the Central African Republic: honey, medicinal plants, okok (Gnetum africanum), bush mangoes (Irvingia ssp.), cola nuts (Cola spp.), palm wine and mats (Raphia spp., Elaeis guineensis), caterpillars, mushrooms, and arrowroot (Marantaceae) leaves.

Third, knowing the current fragility of the forest sector in the region, specifically FSC-certified companies (Karsenty, 2018), we promote the new model of "Concessions 2.0" adapted to the future challenges of Central African forests (Karsenty and Vermeulen, 2016). This model suggests a shift from the classic logging concession system solely involving the state and the private sector for wood exploitation. It moves towards a new model of governance based on a multi-stakeholder platform (including local populations and local NGOs) empowered to make decisions on the management and marketing of other resources (comprising NTFP) inside the concession. Considering the differences of perceptions of ES abundance among land allocation types for wood and cultural ES, including tourism (Table 2), this model could answer various needs of local populations. Concessions 2.0 would allow associative or commercial valorization of many ES; it combines the mapping and recognition of customary territories inside and around the logging concession, sharing of timber resources and revenue, commercial exploitation of NTFP, and management of overlapping rights through inclusive governance. A better inclusion of all user rights of local populations in the management strategy of the logging concession could avoid major conflicts such as superposition of agricultural and logging activities, severe poaching, and illegal logging (Levang et al., 2015). Concessions 2.0 also constitute an opportunity to develop tourism for the benefit of local communities, with the possible support of another economic operator. To our knowledge, no logging concession in Central Africa is involved in the development of eco-tourism. Tourism ES was perceived by respondents as the least abundant, but there is an eco-tourism potential in the three forest land allocation types, which is slightly exploited only in the protected area. The practical challenges to be overcome include facilitating procedures to obtain visas at the national level, and developing visitor facilities and infrastructure (transport and accommodation) at the local level.

\section{Conclusions}

In this study, we integrated all ecosystem services (ES) that are 
classically attributed to tropical forests in the first social assessment of ES significance and abundance for local populations in southeastern Cameroon. Our results highlighted a high significance of provisioning and cultural \& amenity ES. The perceptions of the abundance of all ES met the ES significance except for bushmeat provision. We identified only slight variations in the perceptions of ES abundance, revealing relative homogeneity and similar ES perceptions among different forest land allocation types and respondents. We proposed eight ES to be quantified with complementary ecological and economic methods, and three concrete recommendations for forest management.

\section{Acknowledgements}

This work was supported by the Fonds pour la Formation à la Recherche dans l'Industrie et dans l'Agriculture (FRIA, F.R.S.-FNRS Fonds de la Recherche Scientifique), and the Fédération Wallonie Bruxelles. Cédric VERMEULEN was funded by a subvention of the CoForTips project, part of the Biodiversa 2012 call for projects and was co-funded by ERA-Net Biodiversa with national donors: ANR (ANR-12EBID-002, France), BELSPO (Belgium), and FWF (Austria). We thank the 225 respondents who participated in the questionnaire surveys, Nature + for their logistical support, Gauthier LIGOT and Yves BROSTAUX for providing assistance with statistical analyses, and Natalie GRAY for proofreading the manuscript and providing constructive comments. We sincerely thank Leon C. BRAAT, the Editor-inChief of the journal, David W. ODEE, the Associate Editor, and five anonymous reviewers for their highly constructive suggestions on the manuscript.

\section{Appendix. Supplementary data}

Supplementary data to this article can be found online at https:// doi.org/10.1016/j.ecoser.2019.100956.

\section{References}

Abernethy, K., Maisels, F., White, L.J.T., 2016. Environmental issues in Central Africa. Annu. Rev. Environ. Resour. 41, 1-33. https://doi.org/10.1146/annurev-environ110615-085415.

Achard, F., Beuchle, R., Mayaux, P., Stibig, H.-J., Bodart, C., Brink, A., Carboni, S. Desclée, B., Donnay, F., Eva, H.D., Lupi, A., Rasi, R., Seliger, R., Simonetti, D., 2014. Determination of tropical deforestation rates and related carbon losses from 1990 to 2010. Glob. Change Biol. 20, 2540-2554. https://doi.org/10.1111/gcb.12605.

Alassaf, A., Alhunaiti, D., Dick, J., Al-Adwan, T., 2014. Differences in perceptions, attitudes, and use of ecosystem services among diverse communities in an arid region: a case study from the South of Jordan. J. Hum. Ecol. 45, 157-165.

Allendorf, T.D., Yang, J., 2013. The role of ecosystem services in park-people relationships: the case of Gaoligongshan Nature Reserve in southwest China. Biol. Conserv. 167, 187-193. https://doi.org/10.1016/j.biocon.2013.08.013.

Attneave, F., 1962. Perception and related areas. In: Koch, S. (Ed.), Psychology: A Study of a Science. McGraw-Hill, New York, NY, US, pp. 619-659.

Benjamini, Y., Hochberg, Y., 1995. Controlling the false discovery rate: a practical and powerful approach to multiple testing. J. R. Stat. Soc. Ser. B Methodol. 57, 289-300.

Betti, J.L., 2004. Impact of Forest Logging in the Dja Biosphere Reserve, Cameroon (unpublished context study report). Ministry of Environment and Forestry, Cameroon.

Bird, D.K., 2009. The use of questionnaires for acquiring information on public perception of natural hazards and risk mitigation - a review of current knowledge and practice. Nat. Hazards Earth Syst. Sci. 9, 1307-1325.

Boeraeve, F., Dendoncker, N., Sander, J., Gómez-Baggethun, E., Dufrêne, M., 2015. How (not) to perform ecosystem service valuations: pricing gorillas in the mist. Biodivers. Conserv. 24, 187-197. https://doi.org/10.1007/s10531-014-0796-1.

Bohensky, E.L., Reyers, B., Van Jaarsveld, A.S., 2006. Future ecosystem services in a Southern African River Basin: a scenario planning approach to uncertainty. Conserv. Biol. 20, 1051-1061. https://doi.org/10.1111/j.1523-1739.2006.00475.x.

Braat, L.C., de Groot, R., 2012. The ecosystem services agenda: bridging the worlds of natural science and economics, conservation and development, and public and private policy. Ecosyst. Serv. 1, 4-15. https://doi.org/10.1016/j.ecoser.2012.07.011.

Brandon, K., 2014. Ecosystem Services from Tropical Forests: Review of Current Science (Working Paper No. 380), CGD Climat and Forest Paper Series \#7. Center for Global Development, Washington, DC.

Bryan, B.A., Raymond, C.M., Crossman, N.D., Macdonald, D.H., 2010. Targeting the management of ecosystem services based on social values: where, what, and how? Landsc. Urban Plan. 97, 111-122. https://doi.org/10.1016/j.landurbplan.2010.05. 002.
Burkhard, B., de Groot, R., Costanza, R., Seppelt, R., Jørgensen, S.E., Potschin, M., 2012. Solutions for sustaining natural capital and ecosystem services. Ecol. Ind. 21, 1-6. https://doi.org/10.1016/j.ecolind.2012.03.008.

Burkhard, B., Petrosillo, I., Costanza, R., 2010. Ecosystem services - bridging ecology, economy and social sciences. Ecol. Complex. 7, 257-259. https://doi.org/10.1016/j. ecocom.2010.07.001.

Byg, A., Novo, P., Dinato, M., Moges, A., Tefera, T., Balana, B., Woldeamanuel, T., Black, H., 2017. Trees, soils, and warthogs - distribution of services and disservices from reforestation areas in southern Ethiopia. For. Policy Econ. 84, 112-119. https://doi. org/10.1016/j.forpol.2017.06.002.

Caballero-Serrano, V., Alday, J.G., Amigo, J., Caballero, D., Carrasco, J.C., McLaren, B., Onaindia, M., 2017. Social perceptions of biodiversity and ecosystem services in the Ecuadorian Amazon. Hum. Ecol. 45, 475-486. https://doi.org/10.1007/s10745-017. 9921-6.

Carpenter, S.R., DeFries, R., Dietz, T., Mooney, H.A., Polasky, S., Reid, W.V., Scholes, R.J., 2006. Millennium ecosystem assessment: research needs. Science 314, 257-258.

Casado-Arzuaga, I., Madariaga, I., Onaindia, M., 2013. Perception, demand and user contribution to ecosystem services in the Bilbao Metropolitan Greenbelt. J. Environ. Manage. 129, 33-43. https://doi.org/10.1016/j.jenvman.2013.05.059.

Castillo, A., Magaña, A., Pujadas, A., Martínez, L., Godínez, C., 2005. Understanding the interaction of rural people with ecosystems: a case study in a tropical dry forest of Mexico. Ecosystems 8, 630-643. https://doi.org/10.1007/s10021-005-0127-1.

Castro, A.J., Martín-López, B., García-LLorente, M., Aguilera, P.A., López, E., Cabello, J., 2011. Social preferences regarding the delivery of ecosystem services in a semiarid Mediterranean region. J. Arid Environ. 75, 1201-1208. https://doi.org/10.1016/j. jaridenv.2011.05.013.

Cellule Aménagement Pallisco, Nature +, 2015. Résumé des plans d'aménagement et des directives FSC pour les UFA 10-030, 10-031, 10-039, 10-041, 10-042 et 10-044 exploitées par la société Pallisco et ses partenaires.

Challender, D.W.S., MacMillan, D.C., 2014. Poaching is more than an enforcement problem: poaching is more than an enforcement problem. Conserv. Lett. 7, 484-494. https://doi.org/10.1111/conl.12082.

Collins, D., 2003. Pretesting survey instruments: an overview of cognitive methods. Qual. Life Res. 12, 229-238.

Collins, S.L., Carpenter, S.R., Swinton, S.M., Orenstein, D.E., Childers, D.L., Gragson, T.L., Grimm, N.B., Grove, J.M., Harlan, S.L., Kaye, J.P., Knapp, A.K., Kofinas, G.P., Magnuson, J.J., McDowell, W.H., Melack, J.M., Ogden, L.A., Robertson, G.P., Smith, M.D., Whitmer, A.C., 2010. An integrated conceptual framework for long-term social-ecological research. Front. Ecol. Environ. 9, 351-357. https://doi.org/10.1890/ 100068.

Costanza, R., 2000. Social goals and the valuation of ecosystem services. Ecosystems 3, 4-10. https://doi.org/10.1007/s100210000002.

Critchlow, R., Plumptre, A.J., Alidria, B., Nsubuga, M., Driciru, M., Rwetsiba, A., Wanyama, F., Beale, C.M., 2017. Improving law-enforcement effectiveness and efficiency in protected areas using ranger-collected monitoring data. Conserv. Lett. 10, 572-580. https://doi.org/10.1111/conl.12288.

Cuni-Sanchez, A., Pfeifer, M., Marchant, R., Burgess, N.D., 2016. Ethnic and locational differences in ecosystem service values: insights from the communities in forest islands in the desert. Ecosyst. Serv. 19, 42-50. https://doi.org/10.1016/j.ecoser.2016. 04.004.

Dagnelie, P., 2011. Statistique Théorique et Appliquée. Tome 2. Inférence Statistique à une et à Deux Dimensions. De Boeck, Bruxelles.

Dave, R., Tompkins, E.L., Schreckenberg, K., 2016. Forest ecosystem services derived by smallholder farmers in northwestern Madagascar: storm hazard mitigation and participation in forest management. For. Policy Econ. https://doi.org/10.1016/j.forpol. 2016.09.002.

Dawson, N., Martin, A., 2015. Assessing the contribution of ecosystem services to human wellbeing: a disaggregated study in western Rwanda. Ecol. Econ. 117, 62-72. https:// doi.org/10.1016/j.ecolecon.2015.06.018.

de Groot, R.S., Alkemade, R., Braat, L., Hein, L., Willemen, L., 2010a. Challenges in integrating the concept of ecosystem services and values in landscape planning, management and decision making. Ecol. Complex. 7, 260-272. https://doi.org/10.1016/ j.ecocom.2009.10.006.

de Groot, R.S., Fisher, B., Christie, M., Aronson, J., Braat, L., Haines-Young, R., Gowdy, J., Maltby, E., Neuville, A., Polasky, S., et al., 2010b. Integrating the ecological and economic dimensions in biodiversity and ecosystem service valuation. The Economics of Ecosystems and Biodiversity (TEEB): Ecological and Economic Foundations. Earthscan.

de Groot, R.S., Wilson, M.A., Boumans, R.M., 2002. A typology for the classification, description and valuation of ecosystem functions, goods and services. Ecol. Econ. 41, 393-408.

de Wasseige, C., Tadoum, M., Atyi, E., Doumenge, C. (Eds.), 2015. The forests of the Congo Basin - Forests and climate change, Weyrich. ed. Belgium.

Díaz, S., Pascual, U., Stenseke, M., Martín-López, B., Watson, R.T., Molnár, Z., Hill, R., Chan, K.M.A., Baste, I.A., Brauman, K.A., Polasky, S., Church, A., Lonsdale, M., Larigauderie, A., Leadley, P.W., van Oudenhoven, A.P.E., van der Plaat, F., Schröter, M., Lavorel, S., Aumeeruddy-Thomas, Y., Bukvareva, E., Davies, K., Demissew, S., Erpul, G., Failler, P., Guerra, C.A., Hewitt, C.L., Keune, H., Lindley, S., Shirayama, Y., 2018. Assessing nature's contributions to people. Science 359, 270-272. https://doi. org/10.1126/science.aap8826.

Diaz, S., Quetier, F., Caceres, D.M., Trainor, S.F., Perez-Harguindeguy, N., Bret-Harte, M.S., Finegan, B., Pena-Claros, M., Poorter, L., 2011. Linking functional diversity and social actor strategies in a framework for interdisciplinary analysis of nature's benefits to society. Proc. Natl. Acad. Sci. 108, 895-902. https://doi.org/10.1073/pnas. 1017993108.

Endamana, D., Angu, K.A., Akwah, G.N., Shepherd, G., Ntumwel, B.C., 2016. 
Contribution of non-timber forest products to cash and non-cash income of remote forest communities in Central Africa. Int. For. Rev. 18, 280-295. https://doi.org/10. $1505 / 146554816819501682$.

Ezzine de Blas, D., Ruiz-Pérez, M., Vermeulen, C., 2011. Management conflicts in Cameroonian community forests. Ecol. Soc. 16, 8.

Fagerholm, N., Kaeyhko, N., Ndumbaro, F., Khamis, M., 2012. Community stakeholders' knowledge in landscape assessments - mapping indicators for landscape services. Ecol. Ind. 18, 421-433.

Farley, J., 2012. Ecosystem services: the economics debate. Ecosyst. Serv. 1, 40-49. https://doi.org/10.1016/j.ecoser.2012.07.002.

Fayolle, A., Swaine, M.D., Bastin, J.-F., Bourland, N., Comiskey, J.A., Dauby, G., Doucet, J.-L., Gillet, J.-F., Gourlet-Fleury, S., Hardy, O.J., Kirunda, B., Kouamé, F.N., Plumptre, A.J., 2014. Patterns of tree species composition across tropical African forests. J. Biogeogr. 41, 2320-2331. https://doi.org/10.1111/jbi.12382.

Felipe-Lucia, M.R., Comín, F.A., Escalera-Reyes, J., 2015. A framework for the social valuation of ecosystem services. Ambio 44, 308-318. https://doi.org/10.1007/ s13280-014-0555-2.

Fenton, I., 2012. Five rainforest ecosystem services that nourish people and the planet [WWW Document]. Nourishing Planet. URL http://blogs.worldwatch.org/ nourishingtheplanet/five-rainforest-ecosystem-services-that-nourish-people-and-theplanet/ (accessed 8.2.16)

Foerster, S., Wilkie, D.S., Morelli, G.A., Demmer, J., Starkey, M., Telfer, P., Steil, M., Lewbel, A., 2012. Correlates of bushmeat hunting among remote rural households in Gabon, Central Africa. Conserv. Biol. 26, 335-344. https://doi.org/10.1111/j.15231739.2011.01802.x.

Friant, S., Paige, S.B., Goldberg, T.L., 2015. Drivers of bushmeat hunting and perceptions of zoonoses in Nigerian hunting communities. PLoS Negl. Trop. Dis. 9, e0003792. https://doi.org/10.1371/journal.pntd.0003792.

García-Llorente, M., Castro, A.J., Quintas-Soriano, C., López, I., Castro, H., Montes, C., Martín-López, B., 2016. The value of time in biological conservation and supplied ecosystem services: a willingness to give up time exercise. J. Arid Environ. 124, 13-21. https://doi.org/10.1016/j.jaridenv.2015.07.004.

García-Llorente, M., Martín-López, B., Iniesta-Arandia, I., López-Santiago, C.A., Aguilera, P.A., Montes, C., 2012. The role of multi-functionality in social preferences toward semi-arid rural landscapes: an ecosystem service approach. Environ. Sci. Policy 19-20, 136-146. https://doi.org/10.1016/j.envsci.2012.01.006.

Geijzendorffer, I.R., Roche, P.K., 2014. The relevant scales of ecosystem services demand. Ecosyst. Serv. 10, 49-51. https://doi.org/10.1016/j.ecoser.2014.09.002.

Gelcich, S., Defeo, O., Iribarne, O., Del Carpio, G., DuBois, R., Horta, S., Pablo Isacch, J., Godoy, N., Coayla Peñaloza, P., Carlos Castilla, J., 2009. Marine ecosystem-based management in the Southern Cone of South America: stakeholder perceptions and lessons for implementation. Mar. Policy 33, 801-806. https://doi.org/10.1016/j. marpol.2009.03.002.

Gelcich, S., O'Keeffe, J., 2016. Emerging frontiers in perceptions research for aquatic conservation. Aquat. Conserv. Mar. Freshw. Ecosyst. 26, 986-994. https://doi.org/ 10.1002/aqc. 2714.

Gillet, P., Feintrenie, L., Codina Llavina, E., Lehnebach, C., Vermeulen, C., 2015. The effect of deforestation rate on land tenure in Central Africa, in: Linking Land Tenure and Use for Shared Prosperity. Presented at the Annual World Bank Conference on Land and Poverty, Washington DC.

Gillet, P., Vermeulen, C., Doucet, J.-L., Codina, E., Lehnebach, C., Feintrenie, L., 2016. What are the impacts of deforestation on the harvest of non-timber forest products in Central Africa? Forests 7, 106. https://doi.org/10.3390/f7050106.

Guerbois, C., Fritz, H., 2017. Patterns and perceived sustainability of provisioning ecosystem services on the edge of a protected area in times of crisis. Ecosyst. Serv. 28, 196-206. https://doi.org/10.1016/j.ecoser.2017.11.010.

Guthrie, M., 1948. The Classification of the Bantu Languages. Londres.

Hansen, M.C., Potapov, P.V., Moore, R., Hancher, M., Turubanova, S.A., Tyukavina, A., Thau, D., Stehman, S.V., Goetz, S.J., Loveland, T.R., Kommareddy, A., Egorov, A., Chini, L., Justice, C.O., Townshend, J.R.G., 2013. High-resolution global maps of 21st-century forest cover change. Science 342, 850-853. https://doi.org/10.1126/ science.1239552.

Hartter, J., 2010. Resource use and ecosystem services in a forest park landscape. Soc. Nat. Resour. Int. J. 23, 207-223. https://doi.org/10.1080/08941920903360372.

Hartter, J., Goldman, A., 2011. Local responses to a forest park in western Uganda: alternate narratives on fortress conservation. Oryx 45, 60-68. https://doi.org/10. 1017/S0030605310000141.

Hartter, J., Solomon, J., Ryan, S.J., Jacobson, S.K., Goldman, A., 2014. Contrasting perceptions of ecosystem services of an African forest park. Environ. Conserv. 41, 330-340. https://doi.org/10.1017/S0376892914000071.

Hicks, C.C., Cinner, J.E., 2014. Social, institutional, and knowledge mechanisms mediate diverse ecosystem service benefits from coral reefs. Proc. Natl. Acad. Sci. 111, 17791-17796. https://doi.org/10.1073/pnas.1413473111.

Hicks, C.C., Graham, N.A.J., Cinner, J.E., 2013. Synergies and tradeoffs in how managers, scientists, and fishers value coral reef ecosystem services. Glob. Environ. Change 23, 1444-1453. https://doi.org/10.1016/j.gloenvcha.2013.07.028.

Hijmans, R.J., Cameron, S.E., Parra, J.L., Jones, P.G., Jarvis, A., 2005. Very high resolution interpolated climate surfaces for global land areas. Int. J. Climatol. 25, 1965-1978. https://doi.org/10.1002/joc.1276.

Iftekhar, M.S., Takama, T., 2007. Perceptions of biodiversity, environmental services, and conservation of planted mangroves: a case study on Nijhum Dwip Island. Bangladesh. Wetl. Ecol. Manag. 16, 119-137. https://doi.org/10.1007/s11273-007-9060-8.

Ingram, V., Ndoye, O., Iponga, D.M., Tieguhong, J.C., Nasi, R., 2012. Les produits forestiers non ligneux: contribution aux économies nationales et stratégies pour une gestion durable, in: Les Forêts Du Basin Du Congo - Etat Des Forêts 2010. Luxembourg, p. 276.
Jacobs, S., Dendoncker, N., Martin-Lopez, B., Barton, D.N., Gomez-Baggethun, E., Boeraeve, F., McGrath, F., Vierikko, K., Geneletti, D., Katharina, S.J., Pipart, N., Primmer, E., Mederly, P., Schmidt, S., Aragão, A., Baral, H., Bark, R., Briceno, T., Brogna, D., Cabral, P., De Vreese, R., Liquete, C., Mueller, H., Peh, K.S.-H., Phelan, A., Rincon, A., 2016. A new valuation school: integrating diverse values of nature in resource and land use decisions. Ecosyst. Serv. 22, 213-220.

Janssen, M.A., Anderies, J.M., Ostrom, E., 2007. Robustness of social-ecological systems to spatial and temporal variability. Soc. Nat. Resour. 20, 307-322. https://doi.org/ 10.1080/08941920601161320.

Karjalainen, T.P., Marttunen, M., Sarkki, S., Rytkönen, A.-M., 2013. Integrating ecosystem services into environmental impact assessment: an analytic-deliberative approach. Environ. Impact Assess. Rev. 40, 54-64. https://doi.org/10.1016/j.eiar.2012.12.001.

Karsenty, A., 2018. La crise de la Filière Européenne du bois Tropical en Afrique Centrale. WillAgri.

Karsenty, A., Vermeulen, C., 2016. Toward "Concessions 2.0": articulating inclusive and exclusive management in production forests in Central Africa. Int. For. Rev. 18, 13

Kovács, E., Kelemen, E., Kalóczkai, Á., Margóczi, K., Pataki, G., Gébert, J., Málovics, G. Balázs, B., Roboz, Á., Krasznai Kovács, E., Mihók, B., 2015. Understanding the links between ecosystem service trade-offs and conflicts in protected areas. Ecosyst. Serv. 12, 117-127. https://doi.org/10.1016/j.ecoser.2014.09.012.

Kremen, C., Ostfeld, R.S., 2005. A call to ecologists: measuring, analyzing, and managing ecosystem services. Front. Ecol. Environ. 3, 540-548.

Lescuyer, G., 2010. Importance économique des produits forestiers non ligneux dans quelques villages du Sud-Cameroun. Bois For. Trop. 304, 15-24.

Letouzey, R., 1985. Carte phytogéographique du Cameroun.

Levang, P., Lescuyer, G., Noumbissi, D., Déhu, C., Broussolle, L., 2015. Does gathering really pay? case studies from forest areas of the East and South regions of Cameroon. For. Trees Livelihoods 24, 128-143. https://doi.org/10.1080/14728028.2014. 1000980.

Lindsey, P.A., Balme, G., Becker, M., Begg, C., Bento, C., Bocchino, C., Dickman, A., Diggle, R.W., Eves, H., Henschel, P., Lewis, D., Marnewick, K., Mattheus, J., Weldon McNutt, J., McRobb, R., Midlane, N., Milanzi, J., Morley, R., Murphree, M., Opyene, V., Phadima, J., Purchase, G., Rentsch, D., Roche, C., Shaw, J., van der Westhuizen, H., Vliet, N.V., Zisadza-Gandiwa, P., 2013. The bushmeat trade in African savannas: impacts, drivers, and possible solutions. Biol. Conserv. 160, 80-96. https://doi.org/ 10.1016/j.biocon.2012.12.020.

Malhi, Y., Gardner, T.A., Goldsmith, G.R., Silman, M.R., Zelazowski, P., 2014. Tropical forests in the anthropocene. Annu. Rev. Environ. Resour. 39, 125-159. https://doi. org/10.1146/annurev-environ-030713-155141.

Mallon, D.P., Hoffmann, M., McGowan, P.J.K., 2015. An IUCN Situation Analysis of Terrestrial and Freshwater Fauna in West and Central Africa (Occasional Paper No. 54). IUCN Species Survival Commission, Gland, Switzerland and Cambridge, UK doi: 10.2305/IUCN.CH.2015.SSC-OP.54.en.

Martín-López, B., Gómez-Baggethun, E., García-Llorente, M., Montes, C., 2014. Trade-offs across value-domains in ecosystem services assessment. Ecol. Ind. 37, 220-228. https://doi.org/10.1016/j.ecolind.2013.03.003.

Martín-López, B., Iniesta-Arandia, I., García-Llorente, M., Palomo, I., Casado-Arzuaga, I., Amo, D.G.D., Gómez-Baggethun, E., Oteros-Rozas, E., Palacios-Agundez, I., Willaarts, B., González, J.A., Santos-Martín, F., Onaindia, M., López-Santiago, C., Montes, C., 2012. Uncovering ecosystem service bundles through social preferences. PLoS one 7 , e38970. https://doi.org/10.1371/journal.pone.0038970.

Menzel, S., Teng, J., 2009. Ecosystem services as a stakeholder-driven concept for conservation science: participative ecosystem services. Conserv. Biol. 24, 907-909. https://doi.org/10.1111/j.1523-1739.2009.01347.x.

Mertens, B., Lambin, E.F., 1997. Spatial modelling of deforestation in southern Cameroon. Appl. Geogr. 17, 143-162.

Meutchieye, F., Tsafo, K.E.C., Niassy, S., 2016. Inventory of edible insects and their harvesting methods in the Cameroon centre region. J. Insects Food Feed 2, 145-152. https://doi.org/10.3920/JIFF2015.0082.

Millennium Ecosystem Assessment, 2005. Ecosystems and Human Well-Being: Synthesis. Island Press, Washington, DC.

Mononen, L., Vihervaara, P., Repo, T., Korhonen, K.T., Ihalainen, A., Kumpula, T., 2017. Comparative study on biophysical ecosystem service mapping methods-a test case of carbon stocks in Finnish Forest Lapland. Ecol. Ind. 73, 544-553. https://doi.org/ 10.1016/j.ecolind.2016.10.003.

Muhamad, D., Okubo, S., Harashina, K., Parikesit, Gunawan, B., Takeuchi, K., 2014. Living close to forests enhances people's perception of ecosystem services in a forest-agricultural landscape of West Java, Indonesia. Ecosyst. Serv. 8, 197-206. https://doi.org/10.1016/j.ecoser.2014.04.003.

Nasi, R., Taber, A., Van Vliet, N., 2011. Empty forests, empty stomachs? Bushmeat and livelihoods in the Congo and Amazon Basins. Int. For. Rev. 13, 355-368. https://doi. org/10.1505/146554811798293872.

Ordaz-Németh, I., Arandjelovic, M., Boesch, L., Gatiso, T., Grimes, T., Kuehl, H.S., Lormie, M., Stephens, C., Tweh, C., Junker, J., 2017. The socio-economic drivers of bushmeat consumption during the West African Ebola crisis. PLoS Negl. Trop. Dis. 11, e0005450. https://doi.org/10.1371/journal.pntd.0005450.

Orenstein, D.E., Groner, E., 2014. In the eye of the stakeholder: Changes in perceptions of ecosystem services across an international border. Ecosyst. Serv. 8, 185-196. https:// doi.org/10.1016/j.ecoser.2014.04.004.

Oyono, P.R., Morelli, T.L., Sayer, J., Makon, S., Djeukam, R., Hatcher, J., Assembe, S., Steil, M., Douard, P., Bigombé, P., Kapa, F., Lima, R., Makak, J.S., Tessa, B., Mbouna, D., Feintrenie, L., Nkoua, M., Ndikumagenge, C., 2014. Allocation and use of forest land: current trends, issues and perspectives, in: Les Forêts Du Bassin Du Congo - État Des Forêts 2013. de Wasseige C., Flynn J., Louppe D., Hiol Hiol F., Mayaux Ph., Neufchâteau, Belgique, pp. 215-240.

Pan, Y., Birdsey, R.A., Fang, J., Houghton, R., Kauppi, P.E., Kurz, W.A., Phillips, O.L., 
Shvidenko, A., Lewis, S.L., Canadell, J.G., Ciais, P., Jackson, R.B., Pacala, S.W., McGuire, A.D., Piao, S., Rautiainen, A., Sitch, S., Hayes, D., 2011. A large and persistent carbon sink in the world's forests. Science 333, 988-993. https://doi.org/10. 1126/science.1201609.

Plieninger, T., Dijks, S., Oteros-Rozas, E., Bieling, C., 2013. Assessing, mapping, and quantifying cultural ecosystem services at community level. Land Use Policy 33, 118-129. https://doi.org/10.1016/j.landusepol.2012.12.013.

Quintas-Soriano, C., Castro, A.J., Castro, H., García-Llorente, M., 2016. Impacts of land use change on ecosystem services and implications for human well-being in Spanish drylands. Land Use Policy 54, 534-548. https://doi.org/10.1016/j.landusepol.2016. 03.011.

Rentsch, D., Damon, A., 2013. Prices, poaching, and protein alternatives: an analysis of bushmeat consumption around Serengeti National Park. Tanzania. Ecol. Econ. 91, 1-9. https://doi.org/10.1016/j.ecolecon.2013.03.021.

Rodríguez, J., Beard Jr, T.D., Bennett, E., Cumming, G., Cork, S., Agard, J., Dobson, A., Peterson, G., 2006. Trade-offs across space, time, and ecosystem services. Ecol. Soc. $11,28$.

Rönnbäck, P., Crona, B., Ingwall, L., 2007. The return of ecosystem goods and services in replanted mangrove forests: perspectives from local communities in Kenya. Environ. Conserv. 34, 313-324. https://doi.org/10.1017/S0376892907004225.

Rosenberg, A.A., McLeod, K.L., 2005. Implementing ecosystem-based approaches to management for the conservation of ecosystem services. Mar. Ecol. Prog. Ser. 300, 270-274.

Santos-Martín, F., Kelemen, E., Jacobs, S., Oteros-Rozas, E., Barton, D.N., Palomo, I., Hevia, V., Martín-López, B., 2017. 4.2. Socio-cultural valuation approaches, in: Mapping Ecosystem Services. Sofia, pp. 102-112.

Sassen, M., Jum, C., 2007. Assessing local perspectives in a forested landscape of Central Cameroon. For. Trees Livelihoods 17, 23-42. https://doi.org/10.1080/14728028. 2007.9752579.

Satz, D., Gould, R.K., Chan, K.M.A., Guerry, A., Norton, B., Satterfield, T., Halpern, B.S., Levine, J., Woodside, U., Hannahs, N., Basurto, X., Klain, S., 2013. The challenges of incorporating cultural ecosystem services into environmental assessment. Ambio 42, 675-684. https://doi.org/10.1007/s13280-013-0386-6.

Sodhi, N.S., Lee, T.M., Sekercioglu, C.H., Webb, E.L., Prawiradilaga, D.M., Lohman, D.J., Pierce, N.E., Diesmos, A.C., Rao, M., Ehrlich, P.R., 2010. Local people value environmental services provided by forested parks. Biodivers. Conserv. 19, 1175-1188. https://doi.org/10.1007/s10531-009-9745-9.

Spangenberg, J.H., Settele, J., 2010. Precisely incorrect? monetising the value of ecosystem services. Ecol. Complex. 7, 327-337.

Turner, R.K., Daily, G.C., 2008. The ecosystem services framework and natural capital conservation. Environ. Resour. Econ. 39, 25-35. https://doi.org/10.1007/s10640007-9176-6.

van Vliet, N., Nasi, R., 2008. Hunting for livelihood in Northeast Gabon: patterns, evolution, and sustainability. Ecol. Soc. 13. https://doi.org/10.5751/ES-02560-130233.

Vermeulen, C., 2000. Le Facteur Humain dans l'aménagement des Espaces-ressources en Afrique Centrale Forestière. Application aux Badjoué de l'Est Cameroun. Faculté Universitaire des Sciences Agronomiques, Gembloux.

Vermeulen, C., Fankap, R., 2001. Exploitation des palmiers et de Garcinia kola pour la fabrication du vin de palme en pays Badjoué ou quand trop boire nuit à la santé... de l'écosystème. In: Delvingt, W. (Ed.), La Forêt des Hommes - Terroirs Villageois en Forêt Tropical Africaine. Belgique, Gembloux, pp. 93-108.

Vermeulen, C., Julve, C., Doucet, J.-L., Monticelli, D., 2009. Community hunting in logging concessions: towards a management model for Cameroon's dense forests. Biodivers. Conserv. 18, 2705-2718. https://doi.org/10.1007/s10531-009-9614-6.

Wangai, P.W., Burkhard, B., Müller, F., 2016. A review of studies on ecosystem services in Africa. Int. J. Sustain. Built Environ. 5, 225-245. https://doi.org/10.1016/j.ijsbe. 2016.08.005.

Warren-Rhodes, K., Schwarz, A.-M., Boyle, L.N., Albert, J., Agalo, S.S., Warren, R., Bana, A., Paul, C., Kodosiku, R., Bosma, W., Yee, D., RöNnbäCk, P., Crona, B., Duke, N., 2011. Mangrove ecosystem services and the potential for carbon revenue programmes in Solomon Islands. Environ. Conserv. 38, 485-496. https://doi.org/10. $1017 /$ S0376892911000373.

Wickam, H., 2009. ggplot2: Elegant Graphics for Data Analysis. Springer-Verlag, New York.

Wilkie, D.S., Starkey, M., Abernethy, K., Effa, E.N., Telfer, P., Godoy, R., 2005. Role of prices and wealth in consumer demand for bushmeat in Gabon, Central Africa. Conserv. Biol. 19, 268-274. https://doi.org/10.1111/j.1523-1739.2005.00372.x.

Wilson, M.A., Carpenter, S.R., 1999. Economic valuation of freshwater ecosystem services in the United States: 1971-1997. Ecol. Appl. 9, 772. https://doi.org/10.2307/ 2641328.

Winterbottom, R., 1992. Tropical forestry actions plans and indigenous people: the case of Cameroon, in: Cleaver, K., Munasinghe, M., Dyson, N., Egli, A., Peuker, F., Wencelius, F. (Eds.), Conservation of West and Central African Rainforest. Washington, DC, pp. 123-125.

World Resources Institute, 2012. Interactive Forest Atlas of Cameroon: Version 3.0. Washington, DC, USA.

Zhang, W., Kato, E., Bhandary, P., Nkonya, E., Ibrahim, H.I., Agbonlahor, M., Ibrahim, H.Y., Cox, C., 2016. Awareness and perceptions of ecosystem services in relation to land use types: evidence from rural communities in Nigeria. Ecosyst. Serv. 22, 150-160. https://doi.org/10.1016/j.ecoser.2016.10.011. 